\title{
Изучение механизмов ингибирования холинэстераз высокими концентрациями положительно заряженных субстратов при конкурирующей кинетике
}

(c) Мухаметгалиева А.P., Массон П.

ФГАОУ ВО «Казанский (Приволжский) фредеральный университет»

Россия, Республика Татарстан, 420008, г. Казань, ул. Кремлевская, 18

“Email: aliya_rafikovna@mail.ru

Ключевые слова: ацетилхолинэстераза, бутирилхолинэстераза, типы ингибирования

Положительно заряженные субстраты холинэстераз (ХЭ) не подчиняются михаэлевскому поведению при взаимодействии высоких концентраций из-за активации / ингибирования фермента [1;2]. Такое каталитическое поведение описывается моделью Вебб-Радича (1). Так как каталитический центр связан с периферическим анионным сайтом (ПАС) с помощью $\Omega$-петли, при взаимодействии избытка субстрата с ПАС происходит аллостерическое взаимодействие и, как следствие, изменяется активность ХЭ (константа $k_{\text {cat }}$ преобразуется в $\left.b \cdot k_{\text {cat }}\right)$.

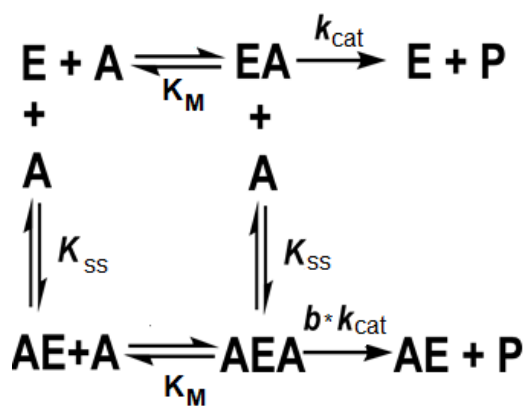

Так как среди природных лигандов положительно заряженным является нейромедиатор ацетилхолин, гидролизуемый ацетилхолинэстеразой (АХЭ), а в некоторых случаях и бутирилхолинэстеразой (БХЭ) [3], данное исследование направлено на изучение выявления механизмов нежелательных конкурирующих взаимодействий (например, с совместно вводимыми лекарственными средствами). Целью работы являлось, установить влияние аллостерического эфффекта, вызванного связыванием второй молекулы ацетилтиохолина, как положительно заряженного субстрата, с ПАС АХЭ и БХЭ при конкурирующей кинетике.

Гидролиз сложных эфиров (тио)холина сопровождается двуступенчатым процессом: образование ацилферментного комплекса и деацилирование ацилферментного комплекса [4]. Чтобы изучить воздействие высоких концентраций положительно заряженных субстратов на механизмы ацилирования и деацилирования и описать механизмы активации/ингибирования, мы использовали пару фенилацетат и ацетилтиохолин, в качестве пары конкурирующих субстратов. Оба исследуемых субстрата имеют ацильный фрагмент - уксусную кислоту, поэтому константа скорости деацилирования для обоих субстратов была одинаковой. 
Кинетическое поведение нехромогенного в ходе анализа субстрата - ацетилтиохолина определяли по гидролизу репортерного субстрата - френилацетата, так как два субстрата будут конкурировать за связывание в активном центре фермента. При использовании широких диапазонов концентраций конкурирующих субстратов было установлено 3 случая ингибирования с помощью кинетики в стационарных условиях (графики Диксона и Корниша-Боудена) [5] и с помощью метода конкурирующих субстратов [6].

Гидролиз фенилацетата в присутствии различных концентраций ацетилтиохолина показал последовательное переключение в связывании субстратов в активном сайте ХЭ. Для обоих ферментов при низких концентрациях ацетилтиохолина (0,025-0,2мМ) наблюдали конкурентное ингибирование; при средних концентрациях ацетилтиохолина (0,5-1,8мМ) было выявлено частично смешанное ингибирование; при высоких концентрациях ацетилтиохолина (2-10мМ) было показано частичное бесконкурентное ингибирование. Три фразы ингибирования в зависимости от концентрации конкурента можно описать следующей схемой (2) [7]:

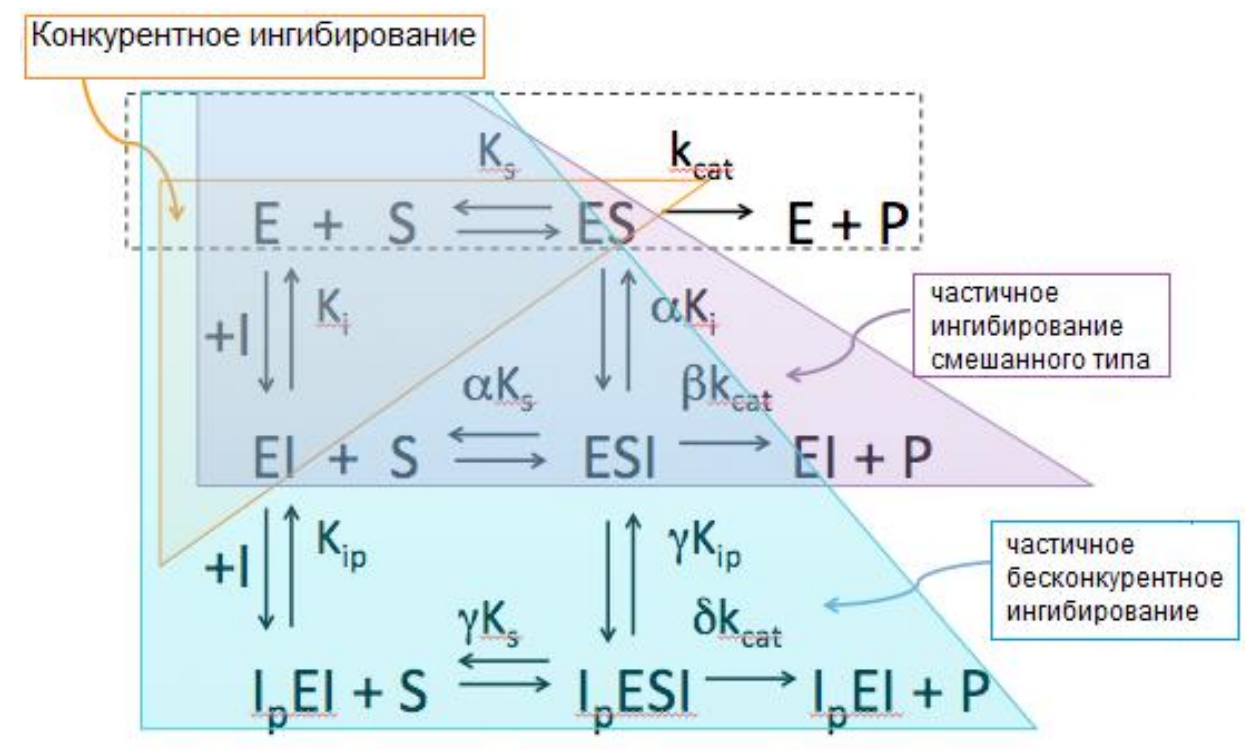

Исследование выполнено за счет гранта Российского научного фронда (проект 20-14-00155).

\section{Литература}

1. Masson P. и др. Role of Aspartate 70 and Tryptophan 82 in Binding of Succinyldithiocholine to Human Butyrylcholinesterase // Biochemistry. 1997. T. 36. № 8. C. 2266-2277. doi: 10.1021/bi962484a.

2. Radic Z. и др. Three distinct domains in the cholinesterase molecule confer selectivity for acetyl- and butyrylcholinesterase inhibitors // Biochemistry. 1993. T. 32. № 45. C. 1207412084. doi: 10.1021/bi00096a018.

3. Duysen E. G. и др. Sensitivity of butyrylcholinesterase knockout mice to (-)-huperzine A and donepezil suggests humans with butyrylcholinesterase deficiency may not tolerate these Alzheimer's disease drugs and indicates butyrylcholinesterase function in neurotransmission // Toxicology. 2007. T. 233. № 1. C. 60-69. doi: 10.1016/j.tox.2006.11.069. 
4. Zhang Y., Kua J., McCammon J.A. (2002) Role of the catalytic triad and oxyanion hole in acetylcholinesterase catalysis: An ab initio QM/MM study. J. Am. Chem. Soc., 124, 1057210577. doi: 10.1021/ja020243m.

5. Cornish-Bowden A. A simple graphical method for determining the inhibition constants of mixed, uncompetitive and non-competitive inhibitors (Short Communication) // Biochem J. 1974. T. 137. № 1. C. 143-144. doi:10.1042/bj1370143

6. Mukhametgalieva A. R. и др. Time-course of human cholinesterases-catalyzed competing substrate kinetics // Chemico-Biological Interactions. 2019. T. 310. C. 108702. doi: 10.1016/j.cbi.2019.06.015.

7. Mukhametgalieva A. R. и др. Steady-state kinetic analysis of human cholinesterases over wide concentration ranges of competing substrates // Biochim Biophys Acta Proteins Proteom. 2021 (в печати). 